\title{
Carex jianfengensis (Carex sect. Rhomboidales, Cyperaceae), a New Species from Hainan, China
}

\author{
Hubiao Yang ${ }^{1 \oplus}$, Xiaoxia Li ${ }^{2 \oplus}$, Wenqiang Wang ${ }^{1}$, Changjun Bai ${ }^{1}$, Guodao Liu ${ }^{1}$ * \\ 1 Tropical Crops Genetic Resources Institute, Chinese Academy of Tropic Agricultural Sciences, Danzhou, \\ Hainan, People's Republic of China, 2 Environment and Plant Protection Institute, Chinese Academy of \\ Tropical Agricultural Sciences, Haikou, Hainan, People's Republic of China \\ ه These authors contributed equally to this work. \\ * liuguodao2008@163.com
}

\section{G open access}

Citation: Yang H, Li X, Wang W, Bai C, Liu G (2015) Carex jianfengensis (Carex sect. Rhomboidales, Cyperaceae), a New Species from Hainan, China. PLOS ONE 10(9): e0136373. doi:10.1371/journal. pone. 0136373

Editor: Yue Wang, National Institute for Viral Disease Control and Prevention, CDC, CHINA

Received: March 30, 2015

Accepted: July 29, 2015

Published: September 23, 2015

Copyright: @ 2015 Yang et al. This is an open access article distributed under the terms of the Creative Commons Attribution License, which permits unrestricted use, distribution, and reproduction in any medium, provided the original author and source are credited.

Data Availability Statement: All relevant data are within the paper.

Funding: This research was financially supported by the Basic Scientific Research Business Expenses (1630032014030), the Earmarked Fund for China Agriculture Research System (CARS-35-03) and the project of tropical forage germplasm resources protection (14RZZY-09). The funders had no role in study design, data collection and analysis, decision to publish, or preparation of the manuscript.

Competing Interests: The authors have declared that no competing interests exist.

\section{Abstract}

A new species of Carex sect. Rhomboidales, C. jianfengensis, is described and illustrated from Hainan, China. The new species is similar to $C$. zunyiensis but differs in having involucral bracts sparsely hispid and with ca. $1 \mathrm{~cm}$ long sheaths; inflorescence with 4 spikes, terminal spike ca. $2.5 \mathrm{~cm}$ long, lateral spikes $2-3.5 \times 0.7-1 \mathrm{~cm}$; staminate glumes narrowly ovate, ca. $5 \mathrm{~mm}$; pistillate glumes triangular-lanceolate, $5-7 \mathrm{~mm}$; perigynia $6-8 \times 3 \mathrm{~mm}$ and pubescent on veins; nutlet 4-5 mm long, rhombic-ovoid, trigonous, base with shortly stipitate, apex abruptly contracted into a erect short beak, and not expanding into an annulate orifice.

\section{Introduction}

The genus Carex L. is one of the largest genera of vascular plants, comprising about 2,000 species distributed almost worldwide in various habitats[1-5]. 527 species in three subgenera and 69 sections were recorded in recently published Flora of China. Recently, additional 18 species have been reported[6-18].

The genus Carex is clearly distinguished from other genera of the Cyperaceae in having consistently unisexual flowers and a perigynium, the latter a sac-like structure of prophyllar origin that surrounds the naked gynoecium[19]. Carex has been divided into subgenera in a number of ways based on the following characters: stigma number, inflorescence structure and distribution of staminate and pistillate flowers within the spikes. The most influential classification was that of Georg Kükenthal who recognized four subgenera: Carex subg. Carex, C. subg. Indocarex, C. subg. Vignea and C. subg. Primocarex. Subsequently, C. subg. Indocarex and C. subg. Primocarex were reclassified as C. subg. Vigneastra [20]. This classification was widely followed by most authors[2,21-25].

Carex sect. Rhomboidales belongs to C. subg. Carex and is characterized by long-sheathing bracts with short blades, trigonous, rhombic to ovoid perigynia with columniform bidentate beaks at the apex, and obovoid or ovoid, trigonous nutlets that are constricted in the middle 
part and mitrate or hastate at the apex[5,20]. The section consists of 41 species, mainly distributed in eastern Asia, with 36 species being native to China and 4 species in Hainan Island. [2, $7-9,11-14,16,21,26-28$,]. Hainan Island is located at the southern part of China, at the northern edge of tropical Asia, with about 4100 vascular plant species. To date, 27 species of Carex have been reported from Hainan[6,14-16,29,].

During an investigation of the flora of Jianfeng Ling Nature Reserve in 2014, a novel species of Carex was collected and is here recognized as a new species in sect. Rhomboidales. Morphologically, the new species has affinities with Carex zunyiensis Tang \& F.T. Wang.

\section{Materials and Methods}

\section{Ethics statement}

The new species reported in this work is collected from Jianfeng Ling Nature Reserve which is protected by the Forestry Bureau of Hainan. Permissions to visit location and field activities were obtained from Jianfeng Ling Nature Reserve Administration Bureau.

\section{Morphological observations}

The morphological description is based on examination of fresh and dried specimens. Details of the staminate terminal spike, the pistillate lateral spikes, the pistillate glume, the perigynium and the nutlet were examined and photographed under a stereomicroscope (Olympus SZX166156). The shapes of perigynium and nutlet were observed using a Philips XL-30E scanning electron microscope. The studied specimens (one holotype, four isotypes, two paratypes) were deposited in the herbaria of the South China Botanical Garden, the Chinese Academy of Sciences (IBSC), and the Tropical Crops Genetic Resources Institute, Chinese Academy of Tropical Agricultural Sciences (TCGRI; not listed in Thiers 2008[30]).

\section{Nomenclatural Acts}

The electronic version of this article in Portable Document Format (PDF) in a work with an ISSN or ISBN will represent a published work according to the International Code of Nomenclature for algae, fungi, and plants, and hence the new names contained in the electronic publication of a PLOS ONE article are effectively published under that Code from the electronic edition alone, so there is no longer any need to provide printed copies.

In addition, new names contained in this work have been submitted to IPNI, from where they will be made available to the Global Names Index. The IPNI LSIDs can be resolved and the associated information viewed through any standard web browser by appending the LSID contained in this publication to the prefix http://ipni.org/. The online version of this work is archived and available from the following digital repositories: PubMed Central, LOCKSS.

\section{Results}

The new species is most similar to C. zunyiensis based on the shape of the leaves, the very short culms and the subbasal and approximate spikes, but differs sufficiently to be recognized as a new species in morphological features (Table 1, Figs 1 and 2).

\section{Taxonomic Treatment}

\section{Carex jianfengensis H.B. Yang, X.X. Li \& G.D. Liu sp. nov. (Figs 1-4)}

The new species is similar to C. zunyiensis, but differs by having sparsely hispid involucral bracts and sheaths, inflorescence with 4 spikes and occasionally 1 lateral spike arising from the 
Table 1. Morphological comparison between Carex jianfengensis and C. zunyiensis. (Figs 1 and 2).

\begin{tabular}{|c|c|c|}
\hline Character & C. jianfengensis & C. zunyiensis \\
\hline Sheaths & $2-7 \mathrm{~cm}$ long and with purple vertical stripes & $\begin{array}{l}\text { basal ones dark brown disintegrating into fibers, upper ones slightly } \\
\text { scabrous on the margin }\end{array}$ \\
\hline Bracts & sparsely hispid and with ca. $1 \mathrm{~cm}$ long sheaths & glabrous, sheathless \\
\hline Inflorescence & $\begin{array}{l}\text { spikes } 4 \text { and occasionally } 1 \text { lateral spike arising from the culm } \\
\text { base }\end{array}$ & spikes $4-7$ \\
\hline Spikes & terminal spike ca. $2.5 \mathrm{~cm}$ long; lateral spikes $2-3.5 \mathrm{~cm}$ long & terminal spike $3.5-5 \mathrm{~cm}$ long; lateral spikes $3-5 \mathrm{~cm}$ long \\
\hline Glumes & $\begin{array}{l}\text { staminate glumes narrowly ovate; pistillate glumes triangular- } \\
\text { lanceolate, 5-7 mm long, green 1-veined, costa excurrent into a } \\
\text { short awn ca. } 2 \mathrm{~mm} \text { long }\end{array}$ & $\begin{array}{l}\text { staminate glumes lanceolate; pistillate glumes lanceolate, ca. } 4 \mathrm{~mm} \\
\text { long, 3-veined, costa excurrent into a scabrous mucro at sharp } \\
\text { apex }\end{array}$ \\
\hline Perigynia & $6-8 \mathrm{~mm}$; densely hispid & $4-5 \mathrm{~mm}$; sparsely hispid \\
\hline Nutlets & $\begin{array}{l}\text { rhombic-ovoid, with angles constricted at the middle, base shortly } \\
\text { stipitate, apex abruptly contracted into an erect short beak and not } \\
\text { expanding into an annulate orifice; epidermal cells with irregularly } \\
\text { 4-5-gonal, central no silica body }\end{array}$ & $\begin{array}{l}\text { ovate-elliptic with angles constricted above, apical beak short, } \\
\text { curved, expanding into an annulate orifice; epidermal cells with } \\
\text { irregularly 5-6-gonal, central with } 1 \text { silica body }\end{array}$ \\
\hline
\end{tabular}

doi:10.1371/journal.pone.0136373.t001

culm base,terminal spike ca. $2.5 \mathrm{~cm}$ long, lateral spikes $2-3.5 \times 0.7-1 \mathrm{~cm}$, staminate glumes narrowly ovate, ca. $5 \mathrm{~mm}$ long, truncate at apex, green 3-veined costa excurrent into a short awn ca. 0.6-0.8 mm long, pistillate glumes triangular-lanceolate, 5-7 mm long, green 3-veined costa excurrent into a short awn ca. $2 \mathrm{~mm}$ long, perigynium 6-8 $\times 3 \mathrm{~mm}$, nutlet rhombicovoid, base shortly stipitate, short beak erect and not expanding into an annulate orifice.

Type. -CHINA. Hainan: Ledong County, Jianfeng Ling Nature Reserve, under forest, alt. 700-900 m, 17 March 2014, Yang Hubiao 20140317001 (holotype, IBSC; isotype, IBSC; TCGRI three duplicates).

Perennial; rhizome short, covered with fibrous remains of old leaf sheath. Culms central, 2 $-4 \times$ ca. $0.2 \mathrm{~cm}$, significantly shorter than leaves, hiding in leaf sheaths, trigonous. Leaves basal, sheathed; blades linear, 25-65 $\times 1-1.6 \mathrm{~cm}$, veins 3-ranked, green, flat, glabrous on both surfaces, apex acuminate; sheaths $2-7 \mathrm{~cm}$ long, with purple vertical stripes, basal ones bladeless. Involucral bracts slightly surpassing inflorescence, leaf-like, sparsely hispid, sheathed; sheaths ca. $1 \mathrm{~cm}$ long, sparsely hispid. Inflorescence of spikes racemose, with 4 spikes, approximate, occasionally 1 lateral spike arising from the culm base. Terminal spike staminate, trigonouscylindrical, ca. $2.5 \mathrm{~cm}$ long; peduncle $2-3.5 \mathrm{~cm}$ long, sparsely hispid. Lateral spikes pistillate, cylindrical, $2-3.5 \times 0.7-1 \mathrm{~cm}$, densely flowered, with peduncle $1-3 \mathrm{~cm}$ long; occasionally peduncle up to $7 \mathrm{~cm}$ long when lowest lateral spike arises from the culm base. Staminate glumes membranous, glabrous, narrowly ovate, ca. $5 \mathrm{~mm}$ long, truncate at apex, green 3-veined costa excurrent into a short awn ca. 0.6-0.8 mm long; pistillate glumes triangular-lanceolate, 5 $-7 \mathrm{~mm}$ long, membranous, glabrous, green 3-veined costa excurrent into a short awn for ca. 2 $\mathrm{mm}$. Perigynia longer than the glumes, green, oval, obscurely trigonous, $6-8 \times 3 \mathrm{~mm}$, membranous, distinctly veined, pubescent on veins, gradually contracted into a ca. $2 \mathrm{~mm}$ long beak; orifice 2-lobed with long teeth. Nutlets tightly enveloped, rhombic-ovoid, trigonous, 4-5 mm long, brownish-black, with angles constricted at the middle, base shortly stipitate, apex abruptly contracted into an erect short beak $1 \mathrm{~mm}$ long; persistent style, base thickened. Flowering and fruiting January to May.

\section{Distribution and Habitat}

Carex jianfengensis was collected from Jianfeng Ling Nature Reserve, Hainan, China. It grows under the tropical mountain rain forest at altitudes of 700-900 m. Associates include Polyspora 
A
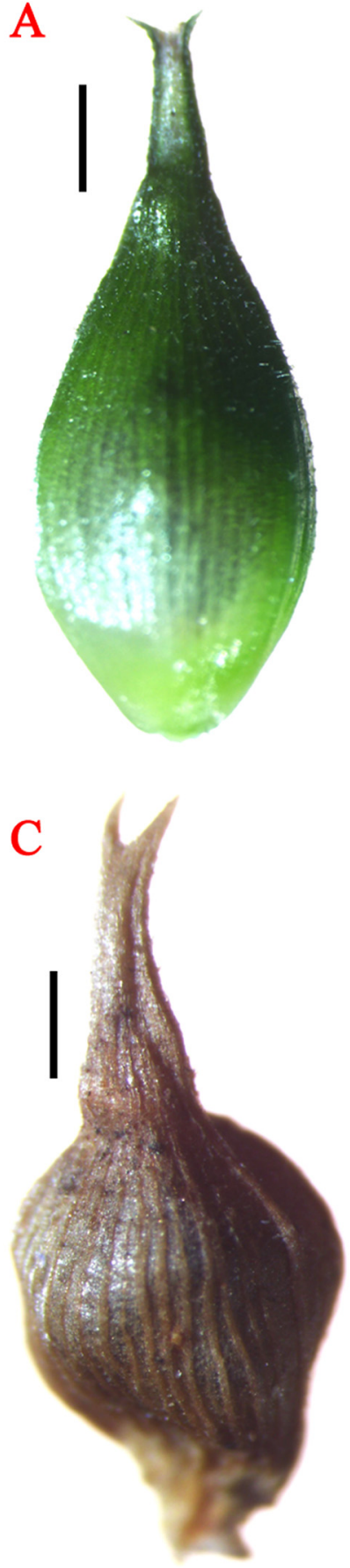
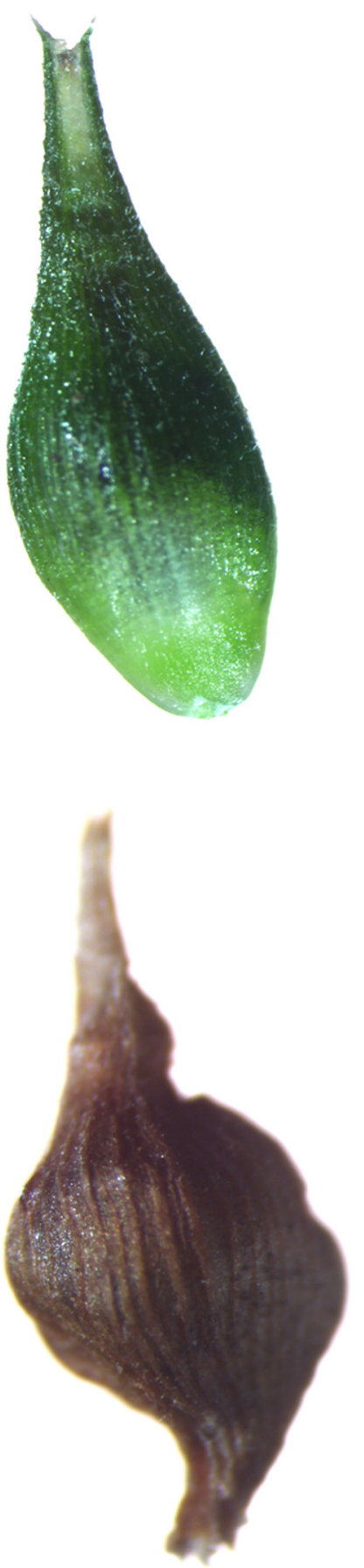

B

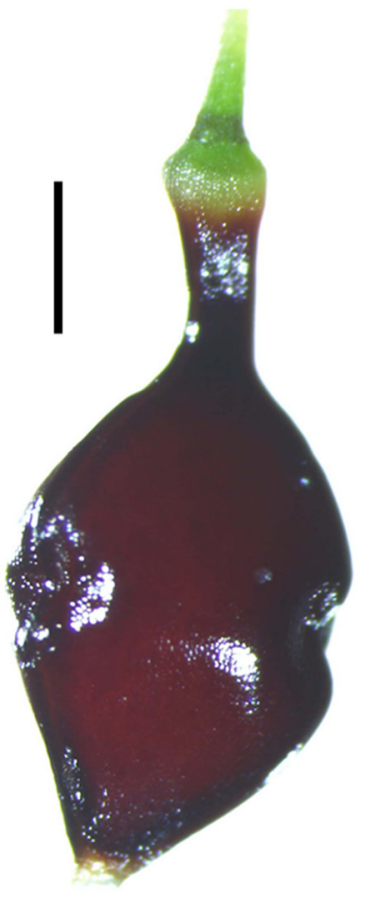

D

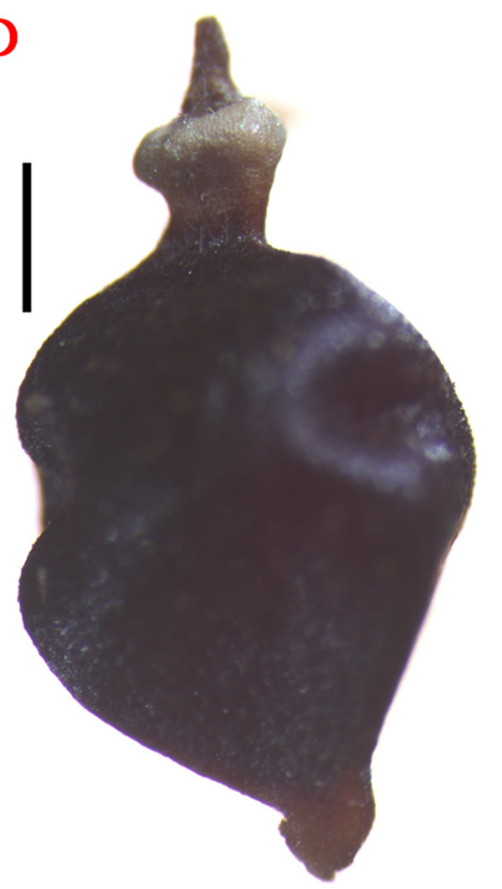

E

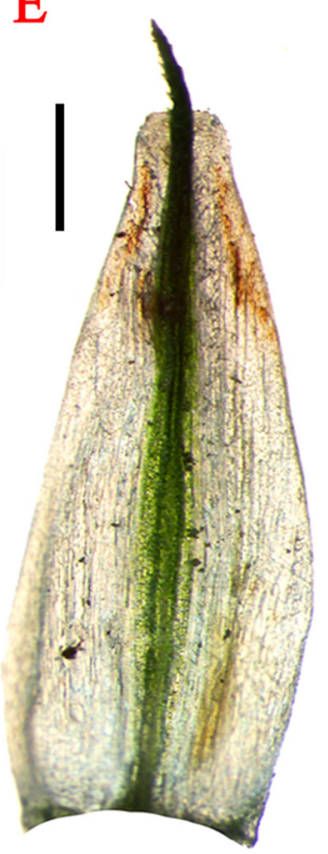

F

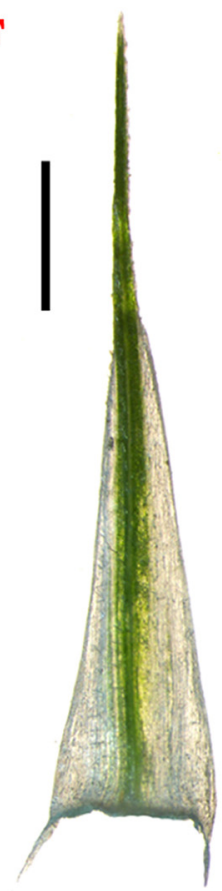

Fig 1. Carex jianfengensis A. Perigynia, B. Nutlet, E. Staminate glume, F. Pistillate glume; C. zunyiensis C. Perigynia. D. Nutlet. (C. zunyiensis from IBSC). Scale bars $=1 \mathrm{~mm}$.

doi:10.1371/journal.pone.0136373.g001

hainanensis (H. T. Chang) C.X. Ye ex B.M. Barthol. \& T.L. Ming, Schima superba Gardner \& Champ., Alsophila spinulosa (Wall. ex Hook.) R.M. Tryon, Schizostachyum pseudolima McClure, Hypolytrum nemorum (Vahl) Spreng., Carex breviscapa C.B. Clarke, and Dianella ensifolia (L.) DC. 


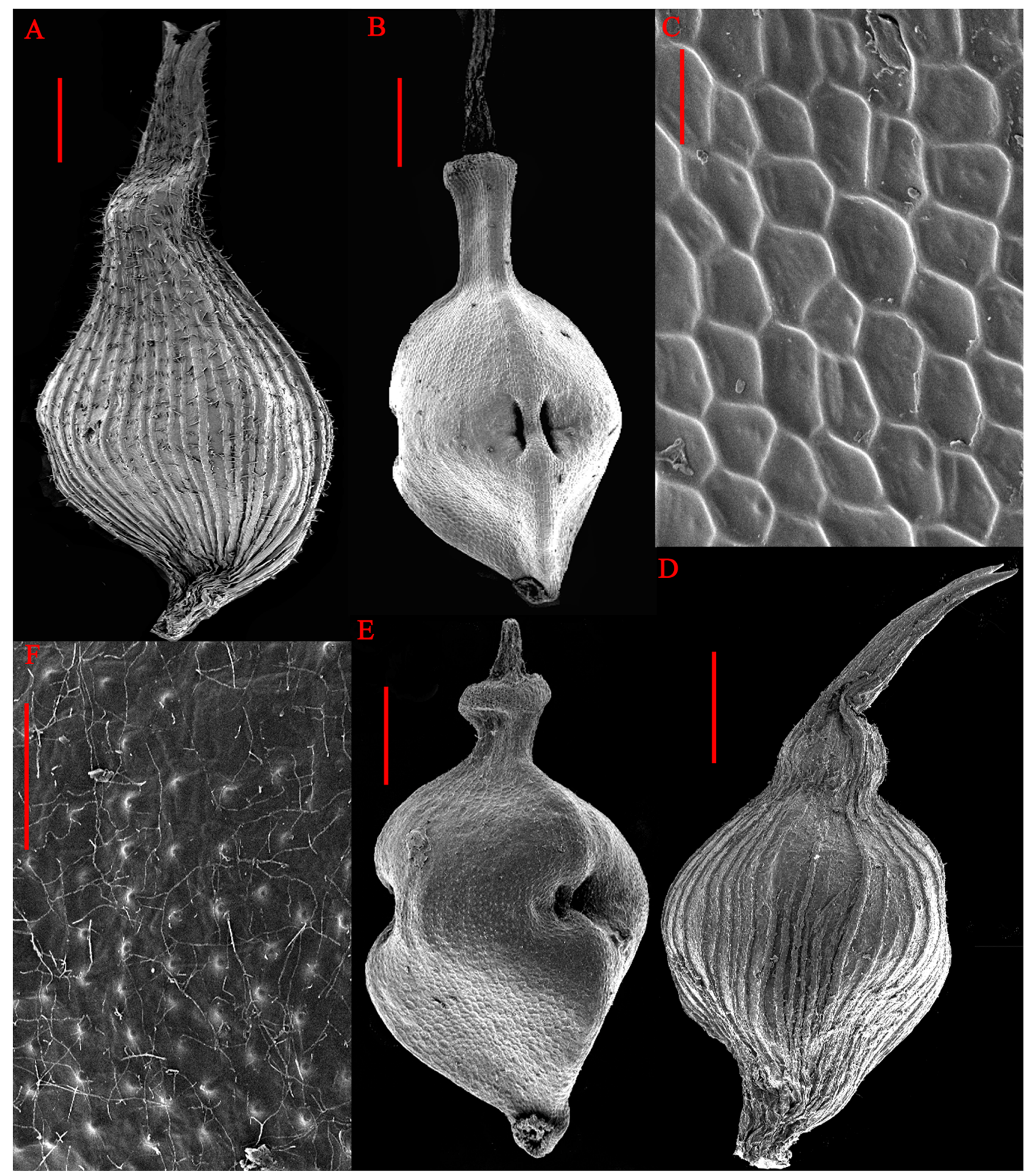

Fig 2. Carex jianfengensis A. Perigynium, B. Nutlet, C. Surface sculpturing; C. zunyiensis D. Perigynium, E. Nutlet, F. Surface sculpturing. (C. zunyiensis from IBSC). Scale bars: A. B. D. $E=1 \mathrm{~mm} ; C=50$ um; $F=100 \mathrm{um}$.

doi:10.1371/journal.pone.0136373.g002 


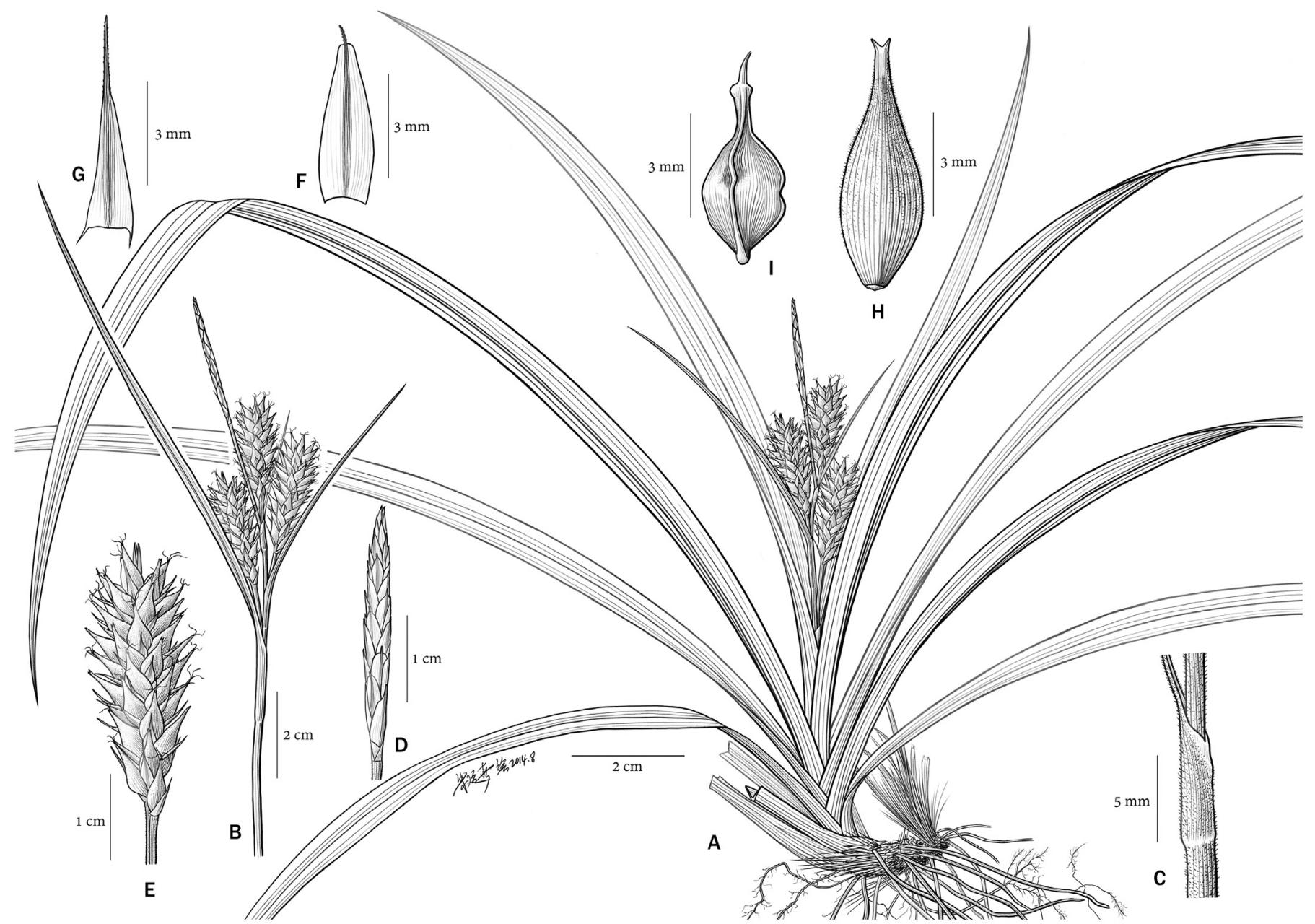

Fig 3. Carex jianfengensis A. Habit; B. Inflorescence; C. Bract sheaths; D. Terminal staminate spike; E. Lateral pistillate spike; F. Staminate glume; G. Pistillate glume; H. Perigynium; I. Nutlet.

doi:10.1371/journal.pone.0136373.g003

\section{Phenology}

Flowering occurs from January and usually seeds mature in March to May.

\section{Etymology}

The epithet “jianfengensis" refers to the type locality, Jianfeng Ling Natural Reserve.

\section{Conservation status}

So far, this species is known from only one population and comprises approximately 2800 caespitose individuals, covers an area of $1000 \mathrm{~m}^{2}$. According to the IUCN (2001) category and criteria, Carex jianfengensis is a vulnerable species (VU).

\section{Relationships}

The new species belongs to Carex sect. Rhomboidales. In Hainan Island, four species, C. harlandii Boott, C. saxicola Tang \& F.T. Wang, C. longipetiolata Q.L. Wang, H.B. Yang \& Y.F. Deng and C. procumbens H.B. Yang, X.X. Li \& G.D. Liu have been reported[14,16]. In addition to the 


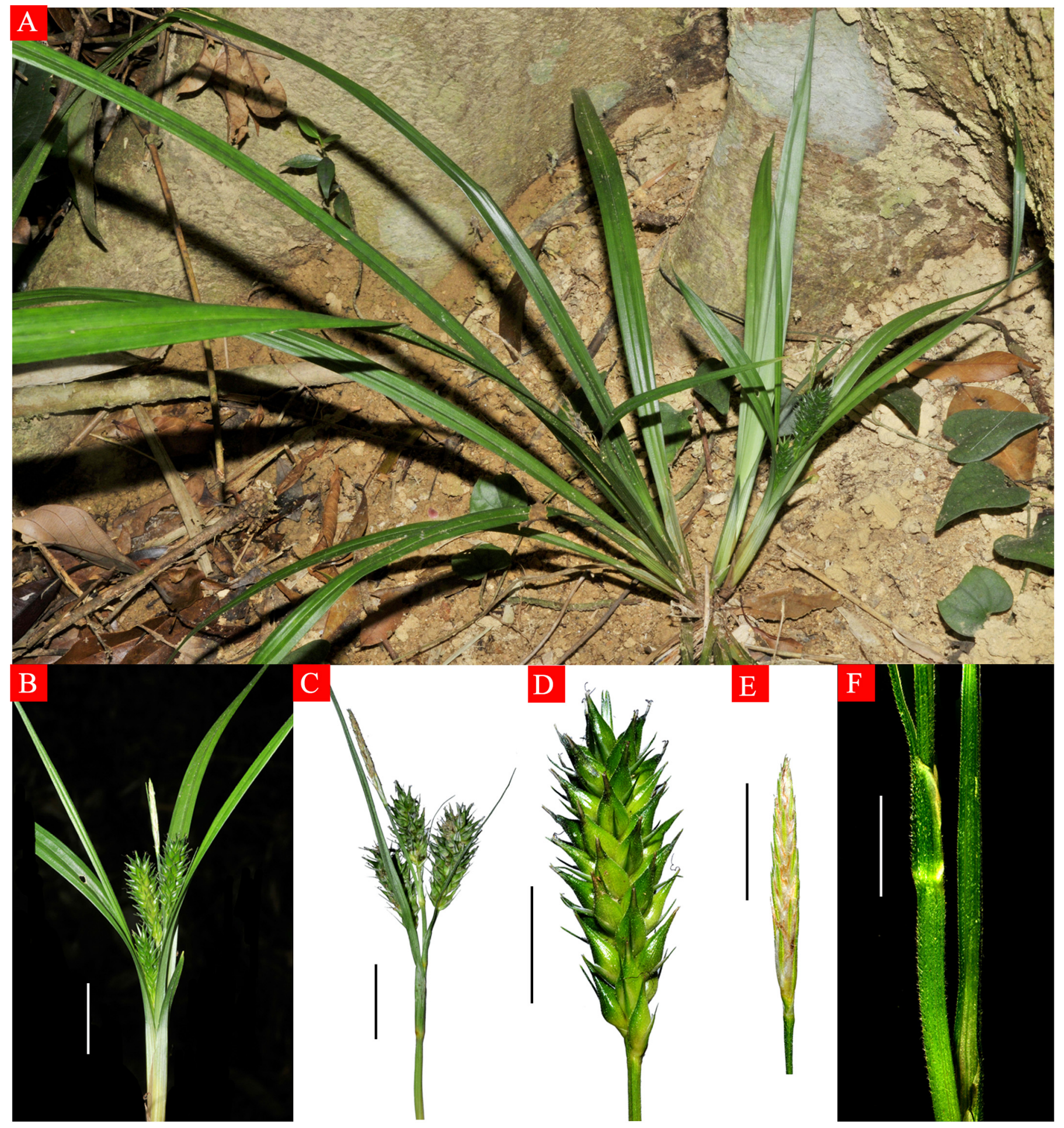

Fig 4. Carex jianfengensis A. Habit, B. Inflorescence, C. Inflorescence, D. Lateral pistillate spike, E. Terminal staminate spike, F. Bract sheaths. doi:10.1371/journal.pone.0136373.g004 
above, 5 new taxa from other regions have recently been described in sect. Rhomboidales: $C$. jubozanensis J. Oda \& A. Tanaka, C. austrozhejiangensis C.Z. Zheng \& X.F. Jin, C. kagoshimensis Tak. Shimizu, C. yandangshanica C.Z. Zheng \& X.F. Jin and C. paracheniana X.F. Jin, D.A. Simpson \& C.Z. Zheng[9,11-13,26]. However, C. jianfengensis can be easily distinguished from species mentioned above by its short culms less than $5 \mathrm{~cm}$ and its subbasal and approximate spikes. It is similar to C. zunyiensis based on the short culms, but differs have been mentioned in above Table 1.

Additional specimens examined (Paratypes). CHINA. Hainan: Ledong County, Jianfeng Ling Nature Reserve, under forest, alt. 700-900 m, 15 April 2014, Yang Hubiao 20140415001 (two duplicates, TCGRI).

\section{Acknowledgments}

This research was financially supported by the Basic Scientific Research Business Expenses (1630032014030), the Earmarked Fund for China Agriculture Research System (CARS-35-03) and the project of tropical forage germplasm resources protection (14RZZY-09). We thank Dr. Yun-Fei Deng and Yi Tong (South China Botanical Garden of the Chinese Academy of Sciences, IBSC) for check herbarium. We are also grateful to Mr. Yu-xi Zhu for his help in preparing the line drawing and Schultze-Kraft Rainer (the International Center for Tropical Agriculture, CIAT) for improving the English.

\section{Author Contributions}

Conceived and designed the experiments: HY XL. Performed the experiments: XL HY. Analyzed the data: HY XL. Contributed reagents/materials/analysis tools: GL CB WW. Wrote the paper: HY XL.

\section{References}

1. Ball PW, Reznicek AA. Carex. In: Ball PW, Reznicek AA, Murray DF. (eds.) Flora of North America: North of Mexico ( vol 23). Oxford University Press, pp. 2003; 254-640.

2. Dai LK, Liang SY, Li PC, Tang YC. Carex (Cyperaceae-Carioideae). In: Dai LK, Liang SY.(eds.) Flora Reipublicae Popularis Sinicae 12. Science Press, Beijing. 2000; pp. 56-528.

3. Frodin DG. History and concepts of big plant genera. Taxon. 2004; 3: 753-776.

4. Nelmes E. The genus Carex in Malaysia. Reinwardtia.1951; 1:221-450.

5. Ohwi J. Cyperaceae Japonicae I. A synopsis of the Caricoideae of Japan, including the Kuriles, Saghalin, Korea and Formosa. Memoirs of the College of Science, Kyoto Imperial University (ser.B). 1936; 11: 229-530.

6. Deng YF. Carex longicolla (Cyperaceae), a new sedge from China. Phytotaxa. 2014; 178(3): 181-188.

7. Jin XF \& Zheng CZ. Taxonomy of Carex sect. Rhomboidales (Cyperaceae). Science Press, Beijing. 2013; $237 \mathrm{pp}$.

8. Jin SH, Zhao YJ, Shen TT, Wu DF, Jin XF. Carex tenuirostrata (Cyperaceae), a new species of section Confertiflorae from Zhejiang, China. Brittonia. 2012a; 64: 325-329.

9. Jin XF, Simpson DA, Zheng CZ, Sun L, Zhang HW. Carex paracheniana (Carex sect. Rhomboidales, Cyperaceae), a new species from Guangxi and Guizhou, China. Syst Bot. 2012b; 37: 929-937.

10. Jin XF, Zhao YJ, Zheng CZ, Zhang HW. Carex zhejiangensis sp. nov. (Cyperaceae) from Zhejiang, eastern China. Nord J Bot 2011; 29: 63-70.

11. Jin XF, Zheng CZ. Carex yandangshanica sp. nov. (Cyperaceae; C. sect. Rhomboidales) from Zhejiang, China. Nord J Bot. 2010; 28: 709-712.

12. Jin XF, Zheng CZ, Ding BY. New taxa of Carex (Cyperaceae) from Zhejiang, China. Acta Phytotaxon Sin. 2004; 42: 541-550.

13. Shimizu T. Carex kagoshimensis, a new species of Carex (sect. Rhomboidales) from Japan. Acta Phytotaxonomica et Geobotanica. 2008; 59: 67-72. 
14. Wang QL, Yang HB, Deng YF, Wang ZN, Liu GD. Carex longipetiolata (Cyperaceae), a new sedge from Hainan, China. Phytotaxa. 2012; 75: 65-69.

15. Yang HB, Wang QL, Bai CJ, Li X X, Liu GD. Carex diaoluoshanica (Carex sect. Lageniformes, Cyperaceae), a New Species from Hainan, China. PLoS ONE. 2014; 9(6): e97658. doi: 10.1371/journal.pone. 0097658

16. Yang HB, Li XX, Chang JB, Wang WQ, Wang QL, Yu DG, Dong RS. Liu GD. Carex procumbens (Carex sect. Rhomboidales, Cyperaceae), a new species from Hainan, China. Phytotaxa. 2015; 201 (3): 207-213.

17. Yu LY, Huang YF, Xu WB, Deng YF. Carex trongii K. K. Nguyen, a newly recorded species of Cyperaceae from China. Journal of Tropical and Subtropical Botany. 2012; 20: 403-406.

18. Zhao YJ, Shen TT, Zheng Y, Chen ZL, Jin XF. Carex dapanshanica sp. nov. (C. sect. Mitratae, Cyperaceae) from Zhejiang, China. Nord J Bot. 2011; 29: 670-673.

19. Blaser HW. Studies in the morphology of the Cyperaceae. I. Morphology of flowers. II. The prophyll. Am J Bot 1944; 31: 53-64.

20. Kükenthal G. Cyperaceae Caricoideae. In: Engler A. (ed.) Das Pflanzenreich IV. 20. Engelmann, Leipzig. 1909; 824 pp.

21. Dai LK, Liang SY, Zhang SR, Tang YC, Koyama T. \& Tucker GC. Carex Linnaeus. In: Wu ZY, Raven PH, Hong DY. (eds.) Flora of China 23. Science Press, Beijing\& Missouri Botanical Garden Press, St. Louis. 2010; pp. 285-461.

22. Koyama T. Classification of the family Cyperaceae (2). Journal of the Faculty of Science, University of Tokyo, Section III. Botany. 1962; 8: 149-278.

23. Reznicek AA. Evolution in sedges (Carex, Cyperaceae). Can J Bot. 1990; 68: 1409-1432.

24. Waterway MJ, Hoshino T, Masaki T. Phylogeny, Species Richness, and Ecological Specialization in Cyperaceae Tribe Cariceae. Bot Rev. 2009; 75: 138-159.

25. Waterway MJ, Starr JR. Phylogenetic relationships in tribe Cariceae (Cyperaceae) based on nested analyses of four molecular data sets. Aliso. 2007; 23:165-192.

26. Oda J, Tanaka A, Naiki A \& Nagamasu H. Carex jubozanensis (Cyperaceae), a new species from Japan. Acta Phytotaxonomica et Geobotanica. 2003; 54: 127-135.

27. Su SW. Carex kobresiformis, a particular species of Carex from China. Journal of Anhui University (Natural Science Edition). 2009a; 33(6): 83-86.

28. Su SW. Additional notes on the genus Carex Linn. from Anhui, China. Journal of Anhui Agricultural University. 2009b; 36: 557-563.

29. Liu GD, Bai CJ. Cyperaceae of Hainan. Science Press, Beijing. 2012; 426 pp.

30. Thiers B. 2008+ (continuously updated): Index herbariorum: a global directory of public herbaria and associated staff. New York Botanical Garden. Published at http://sweetgum.nybg.org/ih/. 